\title{
PENDIDIKAN DI ERA OTONOMI DAERAH PASCA ORDE BARU
}

Junaidi

STAI Darul Hikmah Bangkalan

Email:Lunaidi@darul-hikmah.com

\section{Article History:}

Received: 15-02-2020

Revised: $17-03-2020$

Accepted: 20-03-2020

\begin{abstract}
The education system in Indonesia has experienced many changes since the change in the decentralized political system. Legally, these changes have been legitimized with various applicable laws and regulations. The leading spirit of the decentralization of education is to provide more full opportunities for regional authorities to innovate and take advantage of local excellence in the delivery of instruction. However, in addition to the many positive things that were obtained from the decentralization of education, several unfavorable things happened. Therefore, it is necessary to further and more in-depth study of the effectiveness of the implementation of school with a decentralized pattern.
\end{abstract}

Keywords: education, regional autonomy, the new order

\section{Pendahuluan}

Banyak terjadi perubahan tatanan sosial-politik di Indonesia pasca Era Orde Baru berakhir. Perubahan tersebut membawa harapan dan semangat baru untuk keluar dari belenggu uniformalisme Orde Baru. Pada pemerintahan Orde Baru yang berkuasa lebih dari tiga dekade, mengedepankan kebijakan tiga stabilitas, yaitu stabilitas politik, stabilotas keamanan dan stabilitas ekonomi. Dampak daribkebijakan mempertahankan ketiga stabilitas tersebut adalah penyeragaman ideologi negara berbagai aspek kehidupan berbangsa dan bernegara, termasuk pendidikan. ${ }^{1}$

Pemerintahan Orde Baru menerapkan kebijakan sentralisasi (centralized system) diberbagai linibtermasuk bidang pendidikan. Implikasi kebijakan ini terletak dalam kewenangan mutlak pemerintah pusat Pada sistem pendidikan, anggaran pendidikan, kurikulum, pengadaan media dan sumber belajar, dan sumber daya manusia. Sehingga, institusi pendidikan dan pemerintah daerah tidak memiliki kebijakam dalam mengembangkan pendidikan sesuai inovasi dan distingsi di lingkungannya.

seirring berakhirnya Era Orde Baru pada tahun 1998, berakhir pula sentralisasi dunia pendidikan Indonesia. Era baru yaitu era Reformasi telah membuka lembaran dan harapan baru pendidikan di Indonesia. Sehingga pada Era reformasi ini, sistem

1 Tri W. Ramdhan, "Sekolah dan Masyarakat Berbasis Multikultural", Jurnal Edupedia, Vol. 4 No. 1 (2019), 32. 
pendidikan kedaerahan atau decentralized system mulai diterapkan. Sistem ini memberikan otoritas dan kewenangan kepada pemerintah daerah dan institusi pendidikan dalam membuat kebijakan terkait pendidikan serta secara tidak langsung mengurangi kewenangan pemerintah pusat dalam mengelola pendidikan. ${ }^{2}$

Peralihan sistem ini, pada mulanya disambut dengan antusias, karena di samping sebagai bukti nyata keseriusan pemerintah pasca orde baru untuk mengelola negara secara bersama-sama dengan cara berbagi kewenangan, juga dipandang memberikan peluang para pemangku otoritas pendidikan di berbagai jenjang untuk berkreasi dan melakukan inovasi sesuai dengan kondisi lingkungannya. Dinas pendidikan daerah, yang dulu merupakan Kanwil Departemen Pendidikan, memiliki otoritas lebih besar untuk mengatur lembaga-lembaga pendidikan di daerahnya dalam berbagai aspeknya. Demikian juga halnya dengan lembaga-lembaga pendidikan, mereka memiliki otoritas yang lebih besar untuk menentukan apa yang harus diajarkan di sekolah-sekolah mereka.

Namun demikian, belakangan muncul rasa skeptis atas keberhasilan pengelolaan pendidikan dengan pola desentralisasi ini. Berbagai persoalan muncul sebagai dampak diberikan kewenangan yang besar kepada pemerintah daerah untuk mengelola pendidikan di wilayahnya. Bahkan Kepala Balitbang Kemendikbud mengemukakan bahwa "pelaksanaan otonomi pendidikan yang telah berlangsung lima tahun lebih kerap mengalami banyak hambatan dan permasalahan, yang berpotensi mengganggu efektivitas, efisiensi, dan profesionalisme pengelolaan pendidikan."3

Pernyataan tersebut secara tegas menunjukkan bahwa penyelenggaraan otonomi pendidikan membawa sejumlah masalah serius yang perlu menjadi keprihatinan bersama. Tulisan ini mencoba mengidentifikasi berbagai keuntungan dan persoalan yang dijumpai dengan diberlakukannya otonomi pendidikan. Di bagian akhir akan disampaikan beberapa poin pemikiran yang perlu didskusikan lebih lanjut.

\section{Implikasi Otonomi Daerah: Antara Positif atau Negatif}

Pemberlakuan otonomi daerah dalam bidang pendidikan memiliki aspek yang sangat luas dan meliputi berbagai faktor seperti pengelolaan anggaran, pemanfaatan sumder daya manusia, dan pengembangan potensi lokal lainnya. Kebijakan ini tidak dapat dipungkiri telah memberikan kesempatan kepada pemerintah daerah untuk lebih terlibat

\footnotetext{
${ }^{2}$ Ibid

3"Kemdikbud kaji ulang konsep otonomi pendidikan" diambil dari Kompas Online edisi 29 Nopember 2011.http://edukasi.kompas.com/read/2011/11/29/09304757/Kemdikbud.Kaji.Ulang.Konsep.Otonomi.Pen didikan diakses tanggal 16 April 2019.
} 
dalam pengambilan berbagai kebijakan pendidikan. Diharapkan dengan dekatnya pengambil keputusan dengan institusi yang melaksanakan keputusan tersebut, maka kesenjangan antara harapan dan kenyataan menjadi kian sempit. Dengan kata lain, kebijakan-kebijakan tentang pendidikan diharapkan semakin memperhatikan kebutuhan lembaga-lembaga pendidikan dan para peserta didik, serta semakin aplikatif untuk dilaksanakan.

Ada berbagai dampak positif dari diberlakukannya otonomi daerah dalam hal pendidikan ini. Berbagai dampak positif ini diharapkan dapat memacu pertumbuhan pendidikan nasional, baik dalam hal kuantitatif maupun kualitatif. Secara kuantitatif, pertumbuhan pendidikan dapat dilihat dari meningkatnya akses dan angka partisipasi pendidikan di tiap jenjangnya. Sementara secara kualitatif, peningkatan pendidikan dapat diukur dengan prestasi dan kualitas hasil pendidikan yang dihasilkan. Dengan pemberian otoritas lebih besar kepada pemerintah daerah, ada semacam semangat kompetisi di antara para pemegang otoritas pendidikan antara daerah untuk menunjukkan keberhasilan mereka di bidang pendidikan.

Beberapa dampak positif pemberlakuan otonomi daerah bidang pendidikan antara lain adalah kemandirian daerah, pemanfaatan potensi lokal secara maksimal, dan Lebih peka terhadap kebutuhan lokal. ${ }^{4}$

\section{a. Kemandirian}

Dengan pemberian otoritas kepada daerah untuk mengelola urusan pendidikan, maka pemerintah daerah dituntut untuk mengelola penyenggaraan pendidikan mereka secara mandiri, dan mengurangi ketergantungan pada pemerintah pusat. Kemandirian ini diwujudkan antara lain dengan anggaran pendidikan yang dikelola oleh pemerintah daerah. Di samping itu, pemerintah daerah juga diberi keleluasaan untuk memanfaatkan berbagai sumberdaya pendidikan.

Tantangan yang besar buat pemerintah daerah, terutama di masa-masa transisi dari sentralisasi ke desentralisasi adalah meningkatkan kapasitas, kreativitas dan sensitivitas dalam hal pengelolaan pendidikan.

\section{b. Memaksimalkan Potensi}

Dalam hal potensi lembaga, banyak daerah yang memiliki lembaga-lembaga pendidikan yang memiliki kelebihan-kelebihan tertentu. Keterlibatan masyarakat

\footnotetext{
${ }^{4}$ Tri W. Ramdhan, "Model Pengembangan Kurikulum Multikultural”, Jurnal Al-Insyiroh: Jurnal Studi Keislaman, Vol. 5. No. 2 (2019).
} 
merupakan salah satu kelebihan pengelolaan lembaga pendidikan yang dimiliki daerah. Hal lain yang sering menjadi keunggulan sebuah lembaga pendidikan adalah budaya sekolah yang diciptakan. Budaya sekolah merupakan faktor penting bagi pendidikan karakter siswa.

Potensi sumberdaya manusia meliputi kepemimpinan, tenaga pendidik dan tenaga kependidikan. Salah satu tantangan pengelolaan pendidikan di Era Otonomi daerah menurut Abuddin Nata adalah bagaimana melahirkan kepemimpinan baru. ${ }^{5}$ Di samping itu, daerah diberi keleluasaan untuk mengelola potensi tenaga pendidik dan tenaga kependidikan yang dimilikinya, karena semua tenaga pendidik dan kependidikan yang semua menjadi bagian departemen pendidikan diserahkan kepada daerah masingmasing.

Setiap daerah di Indonesia kaya akan kearifan lokal (local wisdom) dengan berbagai bentuk dan variasinya. Otonomi daerah di bidang pendidikan memberikan kesempatan bagi para pemangku otoritas untuk memanfaatkan berbagai kearifan lokal tersebut, melestarikannya, bahkan menggali berbagai potensi kearifan lokal yang belum dimanfaatkan.

\section{c. Kebutuhan lokal}

Pemberian otoritas yang besar kepada pemerintah daerah untuk mengelola pendidikan telah mendekatkan pengambil kebijakan pendidikan dengan pelaksana pendidikan, yaitu sekolah dan para guru, dan konsumen pendidikan, yaitu masyarakat. Meskipun pendidikan nasional memiliki tujuan ${ }^{6}$ yang sama dan karenanya materi pendidikan pun banyak memiliki kesamaan, namun tidak dapat dapat dipungkiri bahwa setiap daerah memiliki beberapa perbedaan dalam hal kebutuhan pendidikan. Kekhasan daerah akan kebutuhan tersebut antara lain disebabkan oleh kondisi geografis, pengaruh praktek pendidikan di masa lalu, input pendidikan yang tidak merata dan warisan budaya setempat.

Otoritas pendidikan yang sensitif akan berbagai persoalan pendidikan akan mampu mengidentifikasi kebutuhan-kebutuhan pendidikan yang secara spesifik dimiliki oleh daerah maupun oleh lembaga-lembaga pendidikan Kemampuan otoritas pendidikan

5 Abuddin Nata, "Menggagas sistem pendidikan masa depan dalam kerangka pelaksanaan otonomi daerah", Jurnal Didaktika Islamika, Vol. VI, No. 2, (2004), 12.

${ }^{6}$ Menurut UU No. 20 tahun 2003, tujuan pendidikan adalah untuk berkembangnya potensi peserta didik agar menjadi manusia yang beriman dan bertakwa kepada Tuhan Yang MahaEsa, berakhlak mulia, sehat, berilmu, cakap, kreatif, mandiri, dan menjadi warga negara yang demokratis serta bertanggung jawab. 
daerah dalam memperhatikan kebutuhan pendidikan daerahnya pada gilirannya akan mampu meningkatkan akses, partisipasi dan kualitas pendidikan.

Di samping berbagai manfaat dari diberlakukannya sistem desentralisasi pendidikan sebagaimana tersebut di atas, tidak dapat dipungkiri munculnya persoalanpersoalan baru yang perlu mendapat perhatian serius. Berikut adalah beberapa persoalan yang perlu mendapat perhatian bersama.

\section{a. Lokalisasi SDM}

Kewenangan pemerintah daerah untuk mengelola SDM pendidikan seringkali memunculkan sentimen kedaerahan yang berpotensi menimbulkan konflik di kemudian hari. Kewenangan yang besar kepada daerah untuk mengelola sumber daya manusia di bidang pendidikan di daerahnya menyebabkan mengecilnya peluang perpindahan tenaga pendidik dan tenaga kependidikan dari satu daerah ke daerah lain, sehingga proses pembauran antar etnis dari berbagai daerah di Indonesia mengalami hambatan. Hal ini mungkin tidak begitu nampak di kota-kota besar yang multi-etnis, namun akan terasa dampaknya di berbagai daerah yang relatif homogen secara etnis.

Sementara sumberdaya manusia yang dimiliki sangat tidak memadai. Akibatnya, banyak daerah memaksa tenaga pendidik yang ada untuk mengajarkan materi pelajaran di luar bidang keahliannya guna memenuhi tuntutan atas ketersediaan guru di bidangbidang tertentu tersebut.

M. Hidayat mengidentifikasi dua hal persoalan penting dalam hal SDM yang menyebabkan pendidikan di Era Otonomi Daerah tidak bejalan dengan baik, yaitu guru yang kurang profesional dan pejabat yang tidak kompeten. ${ }^{7}$

\section{1) Ketidaksiapan daerah}

Tidak semua daerah memiliki sumberdaya manusia yang memiliki kesiapan yang sama untuk mengelola pendidikan secara baik. Ada daerah yang merespon kewenangan yang besar ini dengan berbagai program yang bertujuan untuk memajukan pendidikan di daerahnya, baik dalam bentuk peningkatan kesejahteraan guru, penyediaan sarana dan prasarana inti dan penunjang yang memadai, pembentukan unit-unit penunjang penyelenggaraan pendidikan, dan sebagainya. Namun demikian, tidak sedikit pula daerah yang melihat pemberian kewenangan ini sebagai peluang untuk berbuat yang menguntungkan bagi peribadi atau kelompoknya.

${ }^{7}$ Lihat M. Hidayat, "Masalah Mutu Pendidikan di Era Otonomi Daerah”, makalah disampaikan di LPMP Sulawesi Selatan, 16 Nopember 2011. 
Dari sinilah muncul kemungkinan terjadinya penyalahgunaan anggaran pendidikan, keberpihakan pada pihak-pihak tertentu yang tidak berorientasi pada kualitas, penerimaan tenaga pendidik dan tenaga kependidikan yang kurang selektif, dan pembuatan program-program yang yang tidak secara substansial menyentuh kebutuhan pendidikan. Meskipun kecurigaan ini perlu dibuktikan secara fakta dan hukum, namun fenomena yang sering ditutup-tutupi ini seolah telah menjadi rahasia umum di berbagai daerah.

Efek lebih lanjut dari ketidak siapan daerah dalam pengelolaan dan penyelenggaraan pendidikan adalah adanya kesenjangan prestasi belajar siswa dari berbagai daerah. Sudah dapat dipastikan bahwa daerah atau kota yang memiliki pendapatan daerah yang lebih besar, fasilitas, sarana dan parasarana pendidikan yang lebih lengkap, serta sumberdaya manusia yang lebih baik mampu menyelenggarakan pendidikan yang lebih berkaulitas serta hasil pendidikan yang lebih kompeten. Sementara sebaliknya daerah-daerah yang memiliki sumber anggaran yang lebih kecil, fasiltas dan sarana yang belum lengkap serta sumberdaya manusia yang belum maksimal, tentu akan sulit mengejar ketertinggalan. Daerah-daerah pada kelompok kedua inilah yang dapat dikatkan kurang siap untuk menyelenggarakan pendidikan secara desentralistik.

\section{Berorientasi Nilai dan kelulusan}

Pemerintah pusat berupaya meminimalisir kesenjangan kualitas pendidikan antar daerah dengan penerapan standar nasional pendidikan ${ }^{8}$ dan penyelenggaraan ujian nasional. Standar nasional mengamanatkan adanya delapan standar yang harus ditetapkan oleh pemerintah guna menghindari kesenjangan kualitas pendidikan, yaitustandarisi, standar proses, standar kompetensi lulusan, standar pendidik dan tenaga kependidikan, standar sarana dan prasarana, standar pengelolaan, standar pembiayaan, dan standar penilaian pendidikan. ${ }^{9}$

Di samping penetapan dan pemberlakuan berbagai standar pendidikan di atas, ujian nasional merupakan salah satu perangkat yang diharapkan mampu mengurangi kesenjangan kualitas pendidikan. Dengan naskah ujian yang dibuat oleh pemerintah pusat, seluruh siswa yang akan menyelesaikan pendidikan pada jenjang pendidikan dasar dan menengah harus mengikuti ujian akhir, dan harus mencapai standar nilai minimum

\footnotetext{
${ }^{8}$ Lihat Peraturan Pemerintah No. 19 tahun 2005 tentang Standar Nasional Pendidikan yang dibuat berdasarkan amanat UU No. 20 tahun 2003.

${ }^{9}$ Untuk penjelasan lebih lanjut tentang berbagai standar tersebut, lihat PP No. 19 tahun 2005.
} 
yang ditetapkan untuk dianggap lulus. Diharapkan pemberlakuan ujian nasional ini dapat memacu para pengemban otoritas pendidikan daerah untuk mampu meningkatkan kualitas pendidikan di daerahnya masing-masing sehingga tidak tertinggal dari daerah lain. Ukurannya adalah pemenuhan nilai standar minimum yang ditetapkan. Di sinilah persoalan besar mulai mengintai. ${ }^{10}$

Bagi sebagian pemerintah daerah, amanat standar nasional pendidikan dan ujian nasional ini merupakan tuntutan untuk meningkatkan kualitas pendidikan di wilayahnya. Bagi sebagian pemerintah daerah yang lain, pemberlakuan ujian nasional merupakan tuntutan untuk menghasilkan siswa yang memiliki hasil ujian yang berada di atas nilai minimum nasional. Perbedaan dalam memandang persoalan ini berimplikasi besar terhadap etika penyelenggaraan pendidikan. Jika pandangan kelompok yang pertama lebih kepada penyediaan layanan pendidikan yang berorientasi kualitas, maka kelompok yang kedua lebih berupaya bagaimana memperoleh nilai ujian yang melebih standar minimum yang ditetapkan, maka kemudian banyak daerah yang mencanangkan lulus UN 100\% sebagai target pencapaian bidang pendidikan. Target yang ditetapkan oleh kepala daerah kemudian disosialisasikan oleh dinas pendidikan dan dibebankan kepada para kepala sekolah untuk pencapaiannya.

Banyak kepala sekolah yang menyadari keterbatasan dan rendahnya kulitas pendidikan yang dimiliki sekolahnya, tetapi mereka tetap dituntut untuk memaksimalkan jumlah lulusan ujian nasional dari lembaga-lembaga pendidikan mereka. Walahsil, berbagai cara, dari yang halal hingga yang haram pun dilakukan. Contoh upaya halal yang menganggu proses pendidikan adalah try-out yang dilakukan berulang-ulang dan pengurangan jumlah jam pelajaran non-UN. Sementara cara haram yang masih ditemukan dalam proses ujian nasional adalah pembocoran naskah ujian ataupun kunci jawabanya dan melakukan kerjasama dengan para pengawas ujian dan pengawas indepneden untuk membiarkan terjadinya perilaku curang dan tidak jujur dalam pelaksanaan ujian nasional. ${ }^{11}$

Orientasi nilai ujian nasional yang menjadi tujuan penyelenggaraan pendidikan daerah dan lembaga-lembaga pendidikan pada gilirannya menciderai bahkan merusak mental penyelenggara pendidikan dan terlebih parah lagi mental para siswa. Seolah

10 B. Arisandhi, "Ujian Nasional Mengkebiri Kedaulatan Guru”. Al-Insyiroh: Jurnal Studi Keislaman, Vol. 1. No. 1 (2015), 15.

11 Ibid 
prinsip menghalalkan segala cara untuk mencapai tujuan menjadi bagian dari proses pendidikan kita.

2. Hilangnya narasi besar pendidikan

Ada satu hal penting yang hilang dari dunia pendidikan kita seiring dengan berlakunya desentralissasi pendidikan, yaitu narasi besar pendidikan nasional. Pada masa lalu, kita sering mendengar nasionalisme dan patriotisme sebagai nilai yang harus ditanamkan lewat pendidikan. Lebih dari itu, nasionalisme dan patriotisme tersebut juga mewarnai berbagai kegiatan lembaga pendidikan baik formal maupun non-formal. Karena itu, tidak heran jika ada kurikulum resmi yang berorientasi pada nasionalisme dan patriotisme, serta ada aktivitas ekstrakurikuler yang berorientasi pada nasionalisme dan patriotisme.

Pada masa orde baru, Pendidikan Pancasila menjadi sebuah narasi besar yang mewarnai hampir seluruh kegiatan berbangsa dan bernegara. Seluruh lembaga formal pendidikan dan lembaga-lembaga non kependidikan diwarnai dengan semangat internalisasi nilai-nilai Pancasila. Terlepas dari hal-hal negatif yang dibawa, pendidikan Pancasila telah menjadi wabah di seluruh Indonesia dan menjadi narasi besar pendidikan nasional.

Dewasa ini, pendidikan kita kehilangan narasi besarnya, sehingga pendidikan nasional seperti kehilangan kepentingan untuk diperjuangkan bersama. Pentingnya narasi besar pendidikan dinyatakan oleh Neil Postman dalam karya provokatifnya "The End of Education." Menurut Postman, pendidikan memerlukan sebuah narasi bersama yang menegaskan identitas bersama, kepentingan bersama dan nilai-nilai moral yang dianut bersama. ${ }^{12}$ Ketiadaan narasi besar yang menyuarakan kepentingan bersama dalam konteks negara, menyebabkan berkurangnya nilai-nilai komunalitas sebagai bangsa. Jika kondisi ini dibiarkan tentu negara ini hanya akan menjadi kumpulan kelompok-kelompok orang yang memiliki dan memperjuangkan kepentingannya masingmasing.

Melihat fenomena yang hadir di dunia pendididikan dewasa ini, dengan ketidakjelasannya narasi bersama dalam pendidikan, maka tidak mengherankan jika para penyelenggara pendidikan, baik di birokrasi pemerintahan, di lembaga pendidikan negeri dan lembaga pendidikan swasta, lebih memprioriatskan kepentingan kelompok kecil

12 Neil Postman, The End of Education: Redefining the value of school (New York: Alfred A Knopf, 1995), 17. 
mereka dan kurang memeperhatikan kepentingan bersama. Masalahnya adalah tidak jelasnya apa yang dimaksud dengan kepentingan bersama dalam pendidikan.Di sinilah nampak bahwa pendidikan kita seperti kehilangan nilai-nilai sejatinya. Pendidikan seolah-olah hanya dijadikan sebagai instrumen untuk menciptakan manusia yang cerdas dan berprestasi.

Ada beberapa narasi bersama yang sering dimunculkan saat ini. Di antaranya adalah internasionalisasi pendidikan dan pendidikan karakter. Dua istilah tersebut dewasa ini ramai dibincangkan dan dikesankan menjadi kepentingan bersama-sama dalam hal pendidikan. Namun demikian keduanya masih perlu diuji lebih lanjut kelayakannya untuk dapat menjadi narasi bersama dalam pendidikan.

\section{Arah Desentralisasi Pendidikan Kita: Sebuah Refleksi}

Politik dan pendidikan adalah dua dari beberapa tema yang senantiasa menarik minat banyak orang untuk berdiskusi. Politik, meski sebatas wacana, sering menjadi bahan diskusi dari berbagai kalangan masyarakat, baik secara formal maupun nonformal. Pendidikan juga sering menjadi bahan diskusi karena penyelenggaraan pendidikan telah menjadi bagian tak terpisahkan dari kehidupan masyarakat Indonesia. Jika masingmasing dari tema politik dan pendidikan telah menjadi tema yang senantiasa menarik untuk didiskusikan, maka tentu akan lebih menarik jika kedua tema itu digabungkan. Tema Pendidikan dan Otonomi Daerah merupakan tema yang menggabungkan dua tema terpisah di atas. Kebijakan pemerintah untuk memberlakukan sistem pendidikan yang desentralistik telah melahirkan berbagai persoalan baru di dunia pendidikan sebagaimana telah dijelaskan di muka. Melihat berbagai persoalan di atas, maka perlu didiskusikan lebih lanjut mengenai hal-hal berikut ini13.

1. Pentingnya narasi besar

Sebagaimana telah dijelaskan di atas, ketiadaan narasi bersama dalam pendidikan telah menyebabkan dunia pendidikan kehilangan misi besarnya. Saat ini ketiadaan narasi itu seolah-olah tertutupi oleh adanya upaya daerah-daerah untuk berkonsentrasi pada peningkatan berbagai aspek pendidikan. Namun pada gilirannya, ketiadaan narasi bersama dalam pendidikan dapat menurunkan kulitas pendidikan dan runtuhnya nilainilai kebangsaan.

13 N. Widiantoro, "Desentralisasi Pendidikan: Proses, Implikasi dan Pengaruhnya Terhadap Arah Pendidikan Nasional”, INSANIA: Jurnal Pemikiran Alternatif Kependidikan, Vol. 15. No. 3 (2015), 453-467. 
Pendidikan yang tidak memiliki narasi bersama, adalah pendidikan yang tidak memperhatikan humanitas manusia. Hal ini karena pendidikan tersebut lebih berorientasi pada kompetensi siswa setelah belajar, bukan pada kualitas pribadi siswa itu sendiri. Oleh karena itu, Postman berpendapat bahwa pendidikan baru dapat dikatakan bermakna apabila guru, orangtua, dana para siswa memiliki kesamaan pandangan dalam melaksanakan pendidikan, baik formal, nonformal dan informal. ${ }^{14}$

Tantangan besar dunia pendidikan dewasa ini adalah memastikan bahwa pendidikan kita memiliki sebuah narasi besar yang mencerminkan kepentingan bangsa dan negara secara umum. Kepentingan bangsa dan negara yang merupakan kepentingan dan kepedulian bersama dapat diwujudkan dalam sebuah narasi besar pendidikan yang akan menjadi rujukan bagi berbagai pihak penyelenggara pendidikan baik formal, nonformal, maupun informal. Oleh karena itu, rumusan mengenai narasi pendidikan harus diperhatikan secara bersama-sama, sehingga kita tidak terjebak pada penyelenggaraan pendidikan yang normatif dan administratif.

2. Orientasi kualitas bukan formalitas

Ada dua fenomena yang belakangan ini menggejala di sekolah-sekolah di Indonesia, yaitu perhatian yang begitu besar terhadap ujian nasional dan keinginan untuk internasionalisasi pendidikan. Bila diperhatikan, sikap berbagai lembaga pendidikan terhadap dua hal tersebut mencerminkan bahwa kebanyakan lembaga pendidikan berorientasi pada formalitas dan bukan kualitas, meskipun sejatinya ujian nasional dan internasionalisasi bertujuan untuk meningkatkan kualitas.

Tuntutan terhadap sekolah dan daerah untuk menghasilkan siswa-siswi yang lulus ujian nasional secara maksimal, telah menyebabkan hilangnya orientasi kualitas pada pendidikan nasional. Setiap daerah dan sekolah seakan berlomba-lomba untuk memperoleh nilai ujian setingi-tingginya sehingga bisa mencapai target jumlah kelulusan siswa. Tuntutan ujian nasional dan implikasinya pada siswa secara nyata telah merubah orientasi atau tujuan pendidikan di daerah dan sekolah. Setiap penyelenggaraan ujian nasional, selalu menyisakan cerita tentang upaya-upaya tidak halal yang dilakukan siswa dengan atau tanpa bantuan sekolah.

Ketika nilai ujian nasional telah menghantui pikiran siswa dan penyelenggara pendidikan, maka pendidikan telah kehilangan arahnya. Oleh sebab itu perlu dipikirkan 
cara untuk merubah cara berpikir (mindset) terhadap penyelenggaraan pendidikan dari pendidikan yang berorientasi semata-mata kelulusan dan nilai, menuju penyelenggaraan yang berorentasi pada kualitas proses dan hasil pendidikan.

Di samping ujian nasional, internasionalisasi pendidikan juga merupakan hal lain yang menghantui pikiran penyelenggara pendidikan. Undang-Undang Sistem Pendidikan Nasional No. 20 tahun 2003 mengamanatkan bahwa Pemerintah dan Pemerintah Daerah "menyelenggarakan sekurang-kurangnya satu satuan pendidikan pada semua jenjang untuk dikembangkan menjadi satuan pendidikan bertaraf internasional."15 Amanat ini membuat pemerintah merumuskan apa yang disebut sebagai Rintisan Sekolah Berstandar Internasional dan Sekolah Berstandar Internasional.

Sekolah-sekolah yang telah memiliki fasilitas yang memadai dan prestasi yang baik dapat membuka kelas-kelas internasional dan menjadi Rintisan Sekolah Berstandar Internasional. Dengan berbagai persyaratan yang ditetapkan oleh Kementerian Pendidikan dan Kebudayaan, banyak sekolah negeri yang berupaya untuk menjadi Sekolah Berstandar Internasional dengan terlebih dahulu menjadi Rintisan Sekolah Berstandar Internasional. Hal menarik yang memicu sekolah sekolah untuk menjadi sekolah RSBI adalah di samping meningkatkan prestise sekolah, juga peluang untuk memperoleh dana tambahan baik dari pemerintah sebagai dana penyiapan RSBI, maupun dari orangtua siswa untuk penyelenggaraan pendidikan.

Fenomena Sekolah Berstandar Internasional tersebut menjadi keprihatinan banyak pihak, karena banyak sekolah yang menjadi RSBI lebih memperhatikan aspek formalitas, seperti ruangan yang eksklusif, guru yang bisa berbahasa Inggris dan biaya yang lebih tinggi. Sementara aspek substansialnya seperti kehilangan arah, sehingga muncul pertanyaan mendaasar, sebenarnya apa yang ingin dicapai dengan sekolah bertaraf internasional.

3. Pemerataan akses dan sumberdaya

Ketika Undang-Undang mengenai otonomi daerah diberlakukan, nampak bahwa kesiapan daerah untuk melaksanakan otonomi bidang pendidikan sangat beragam. Dua persoalan utama yang perlu dicarikan solusinya adalah pemerataan akses dan pengembangan sumber daya manusia.

15 Lihat UU No. 20 tahun 2003, pasal 50 ayat 3. 
Penyediaan atau peningkatan sarana dan pra-sarana pendidikan perlu terus ditingkatkan untuk dapat meningkatkan akses terhadap pendidikan. Persoalan akses tentu tidak mengganggu penyelenggaraan pendidikan di kota-kota yang prasarana transportasinya memadai. Namun ia menjadi masalah besar di daerah-daerah yang memiliki wilayah yang cukup luas, banyak masyarakat yang tinggal di daerah yang sulit dijangkau, dan prasarana transportasi yang kurang memadai. Persoalan geografis dan fasilitas transportasi sering menjadi kendala utama pemerataan akses pendidikan. Pada gilirannya persoalan akses ini juga mempengaruhi tingkat partisipasi pendidikan. Oleh karena itu, perlu dipikirkan berbagai alternatif bagi daerah-daerah yang memiliki masalah dengan keterbatasan akses, karena berbagai kendala di atas.

Sumberdaya, baik manusia maupun benda, juga perlu mendapatkan perhatian serius. Banyak daerah yang melakukan otonomi pendidikan tidak didukung oleh sumberdaya pendidikan yang memadai. Keterbatasan sumberdaya ini terjadi sebagai akibat dari tidak meratanya penyebaran penduduk, tidak seimbangnya penyebaran ekonomi dan tidak meratanya pembangunan. Akibatnya sumberdaya yang baik terkonsentrasi di kota-kota besar.

Perlu ada pemikiran dan upaya serius (affirmative action) untuk membantu daerahdarah yang memiliki sumberdaya yang kurang memadai. Pemerataan sumberdaya dapat dilakukan dengan menyiapkan generasi muda di berbagai daerah untuk meningkatkan kapasitas diri sehingga mampu menciptakan proses pendidikan yang berkualitas. Di samping itu, perlu juga dibuka peluang untuk mendatangkan sumberdaya dari daerah lain guna membantu percepatan pembangunan pendidikan di daerah-daerah yang sumberdayanya relatif memadai. Hal terakhir ini memerlukan campur tangan pemerintah pusat dan keterbukaan pemerintah daerah demi pembangunan pendidikan.

\section{Kesimpulan}

Berbagai persoalan dan pemikiran di atas menunjukkan bahwa pendidikan nasional Indonesia sedang mengalami dinamika yang luar biasa besar. Dinamika ini terjadi karena sebagai negara, Indonesia sedang dalam proses transisi panjang menjadi negara demokrasi. Otonomi daerah dalam penyelenggaraan pendidikan merupakan bagian dari proses transisi tersebut, sehingga tidak mengherankan apabila banyak dijumpai kejanggalan atau anomali dan ketidakpuasan atas apa yang sedang terjadi. 
Kunci keberhasilan pendidikan nasional adalah penyelenggaraan pendidikan di lembaga-lembaga pendidikan. Oleh karenanya lembaga-lembaga pendidikan harus benar-benar disiapkan menjadi lembaga lembaga yang beorientasi pada pengembangan kualitas-kualitas pribadi siswa, tidak hanya mengembangkan intelektualitas dan berpaku pada formalitas. Untuk itu, Mochtar Buchory pernah mengemukakan, bahwa dunia pendidikan kita tidak sekedar memerlukan reformasi seperti yang terjadi di bidang politik dan ekonomi, tetapi ia memerlukan transformasi guna menghasilkan pendidikan yang berkualitas dan berkarakter. ${ }^{16}$ Oleh karenanya, lanjut Buchory, guru harus dilepaskan dari beban politik dan kepentingan sepihak birokrasi, guru harus diberikan keleluasaan untuk mendidik karakter siswa. ${ }^{17}$

\section{Daftar Pustaka}

Arisandhi, B. Ujian Nasional Mengkebiri Kedaulatan Guru.Al-Insyiroh: Jurnal Studi Keislaman, 1(1), 15. 2015.

Bangkalan, S. D. H., \& Ramdhan, T. W. (2019). Model Pengembangan Kurikulum Multikultural. Jurnal Al-Insyiroh: Jurnal Studi Keislaman, Vol. 5, No. 2, (2019).

Buchory, Mochtar. Pendidikan Antisipatoris. Jakarta: Kanisius. 2001.

Buhory, M. H. 'Akuntabilitas Instansi Pemerintah dalam Bidang Pendidikan di Era Otonomi Daerah,' Jurnal Ilmu Pendidikan (Universitas Negeri Malang) Tahun 34 No. 2, Juli 2007.

'Kemdikbud kaji ulang konsep otonomi pendidikan'Kompas Online edisi 29 Nopember 2011

http://edukasi.kompas.com/read/2011/11/29/09304757/Kemdikbud.Kaji.Ulang. Konsep.Otonomi.Pendidikan diakses tanggal 16 April 2019

Hidayat, M. 'Masalah Mutu Pendidikan di Era Otonomi Daerah', makalah disampaikan di LPMP Sulawesi Selatan, 16 Nopember 2011.

Nata, Abuddin. 'Menggagas sistem pendidikan masa depan dalam kerangka pelaksanaan otonomi daerah,' Jurnal Didaktika Islamika (UIN Jakarta), Vol. VI, No. 2, tahun 2004.

Peraturan Pemerintah No. 19 tahun 2005 tentang Standar Nasional Pendidikan

Postman, Neil. The End of Education: Redefining the value of school, New York: Alfred A Knopf, 1995.

16 Mochtar Buchory, Pendidikan Antisipatoris (Jakarta: Penerbit Kanisius, 2001), 71.

17 Ibid., 
Ramdhan, T.W. Kurikulum Pendidikan Islam Multikultural (Analisis Tujuan Taksonomi dan Kompetensi Peserta Didik). Journal PIWULANG, Vol 1. No. 2. 2019.

Ramdhan, T.W. Sekolah dan Masyarakat Berbasis Multikultural. Edupedia, Vol. 4. No. 1. 2019.

Undang-Undang No. 22 tahun 1999 tentang Pemerintahan Daerah

Undang-Undang No. 20 tahun 2003 tentang Sistem Pendidikan Nasional

Undang-Undang No. 32 tahun 2004 tentang Pemerintahan Daerah

Undang-Undang No. 12 tahun 2008 tentang Revisi Kedua atas Undang-Undang No. 32 tahun 2004.

Widiantoro, N. Desentralisasi Pendidikan: Proses, Implikasi dan Pengaruhnya Terhadap Arah Pendidikan Nasional. INSANIA: Jurnal Pemikiran Alternatif Kependidikan, Vol. 15 No. 3, 2010. 